\title{
DOI:http://dx.doi.org/10.18524/1810-4215.2019.32.182511
}

\section{IMAGES DISTRIBUTION OF BINARY SYMMETRICAL GRAVITATIONAL LENS}

\author{
A.T. Kotvytskiy ${ }^{1}$, S.D. Bronza ${ }^{2}$, V.Yu. Shablenko ${ }^{1}$ \\ ${ }^{1}$ Dpt. of Theor. Physics, Karazin Kharkiv National University, \\ Kharkiv, Ukraine,kotvytskiy@gmail.com,shablenkov@gmail.com \\ 2 Dpt. of Further Mathematics, Ukrainian State University of Railway Transport, \\ Kharkiv, Ukraine, bronza.sem@gmail.com
}

ABSTRACT. In this paper, we study the distribution of images from a point source in $N$ - point gravitational lenses.

It is well known that in a Schwarzschild lens $(N=$ 1) from a point source, there are always two images. Moreover, one of them is always inside the Einstein ring, and the second outside it. It follows that:

a) the image plane is divided into two areas;

b) in each area there is always only one image;

c) the source plane, with the exception of the caustic point (origin), is uniquely mapped onto each of the two areas of the image plane.

In our study, we describe an algorithm that allows us to determine the single-valued regions in a 2-point gravitational lens and demonstrate it using an example of a binary symmetric lens in which the distance between the point masses is 1 . We have shown that in this case the full prototype of the caustic divides the image plane into eight simply connected areas that have the following properties:

a) if the point source is inside the caustic, then it has five images in five (internal) areas;

b) if the point source is outside the caustic, then it has three images in three (external) areas;

c) in each area there can be no more than one image;

d) if the image of a point source is located in one of the five internal areas, then the remaining four also have images, while none of the three external areas have images of the source;

e) if the image of the source is located in one of the three external areas, then its images also exist in the remaining two, while none of the five internal areas contains a prototype of this source;

f) a caustic is a continuous, piecewise smooth, closed Jordan curve that has a finite number of singular points; each smooth, open part of the caustic, the ends of which are singular points (the caustic arc) has four inverse images, of which only one belongs to the critical set, the caustic arcs are positively oriented (when going around, the interior of the caustic remains to the left;

g) the boundaries of the regions consist of arcs (closure of the image of arcs) with a hereditary orientation; all eight regions are divided into the following two classes: four regions in which the orientation of the boundary coincides with the orientation on the caustic and four regions in which the orientation of the boundary is opposite to the orientation on the caustic.

Keywords: gravitational lensing: lens mapping, single-valued regions, image distribution.

АНОТАЦІЯ. В даній роботі ми досліджуємо розподіл зображень точкового джерела в $N$ точкових гравітаційних лінзах.

Добре відомо, що в лінзі Шварцшильда $(N=$ 1) від точкового джерела завжди існує два зображення. Причому одно 3 них завжди знаходиться всередині кільця Ейнштейна, а інше зовні нього. Звідси слідує що:

а) площина зображень розбивається на дві області;

b) в кожній області завжди знаходиться лише одне зображення;

с) плоащина джерела, за виключенням точки каустики (початка координат), однозначно відображується на кожну із двух областей плоскості зображень.

В роботі описаний алгоритм, який дозволяє візначити області однозначності в 2-х точковій гравітаційній лінзі. Ми демонструємо його на прикладі бінарної симетричної лінзи в якій відстань між точковими масами дорівнює 1. Ми показали, що в такому випадку повний прообраз каустики розбиває площину зображень на вісім однозв'язних областей. Ці області володіють наступними властивостями:

а) якщо точкове джерело знаходиться всередині каустики, то воно має п'ять зображень в п'яти (внутрішніх) областях;

b) якщо точкове джерело знаходиться зовні 
каустики, то воно має три зображення в трьох (зовнішніх) областях;

c) в кожній області може знаходитися не більше одного зображення;

d) якщо зображення точкового джерела знаходиться в одній із п'яти внутрішніх областей, то в чотирьох областях, що залишилися, також знаходяться зображення, причому в жодній із трьох зовнішніх областей немає зображень джерела;

е) якщо зображення джерела знаходиться в одній iз трьох зовнішніх областей, то в двух областях, що залишилися, також існують його зображення, причому ні в одній із п'яти внутрішніх областей немає прообразу даного джерела;

f) каустика $є$ неперервна, кусочно-гладка, замкнута жорданова крива, що має кінцеве число особливих точок; кожна гладка відкрита частина каустики, кінці якої - особливі точки (дуга каустики) має чотири прообрази, із яких лише один належить критичній множині, дуги каустики зорієнтовані позитивно ( при обході внутрішність каустики залишаеється зліва);

g) границі областей складаються із дуг (замикаючи зображення дуг) 3 спадковою орієнтацією; усі вісім областей діляться на наступні два класи: чотири області, в яких орієнтація границі співпадає 3 орієнтацією на каустиці, та чотири області, в яких орієнтація границі протилежна до орієнтації на каустиці.

Ключові слова: гравітаційне лінзування, лінзове відображення, області однозначності, розподіл зображень.

\section{Introduction}

Gravitational lensing effects (Bliokh\&Minakov, 1989; Zakharov, 1997; Schneider, 1999) are becoming more and more essential, when different astrophysical objects (Gaudi et al. 2008; Han et al. 2013; Gould et al. 2014) and even the whole Universe is studied. From the one hand, it is connected with a development of technologies and engineering solutions. On the other hand, mathematical models development (Bronza \& Kotvytskiy, 2017; Kotvytskiy, Bronza \& Shablenko, 2017; Kotvytskiy \& Bronza, 2016) allows us to do more profound conclusions based on already received observation data. In this study, we show how lens plane can be split into a several areas, where in every area there is the only one point source image. We call the areas as a single-valued region and we study their properties.

\section{General approach}

System of equations that describes $N$-point gravitational lens is:

$$
\left\{\begin{array}{c}
y_{1}=x_{1}-\sum_{n=1}^{N} m_{n} \frac{x_{1}-a_{n}}{\left(x_{1}-a_{n}\right)^{2}+\left(x_{2}-b_{n}\right)^{2}} \\
y_{2}=x_{2}-\sum_{n=1}^{N} m_{n} \frac{x_{2}-a_{n}}{\left(x_{1}-a_{n}\right)^{2}+\left(x_{2}-b_{n}\right)^{2}}
\end{array}\right.
$$

where $y_{1}, y_{2}$ - dimensionless coordinates of point source, $x_{1}, x_{2}$ - dimensionless image positions, $\left(a_{n}, b_{n}\right)$ - coordinates of point masses $m_{n}$. Dimensionless point masses are normalized:

$$
\sum_{n=1}^{N} m_{n}=1 .
$$

Equation (1) gives a single-valued mapping $L$

$$
L:\left(R_{X}^{2} \backslash A\right) \rightarrow R_{Y}^{2}
$$

of lens plane $R_{X}^{2}$, where points with point masses are deleted, to source plane $R_{Y}^{2}$.

We introduce new complex variables $z$ и $\zeta$

$$
z=x_{1}+x_{2} i, \zeta=y_{1}+y_{2} i .
$$

Then system of equations (1) becomes (Kotvytskiy\& Shablenko\&Bronza, 2018):

$$
\zeta=z-\overline{\sum_{n=1}^{N} m_{n} \frac{1}{z-A_{n}},}
$$

where $A_{n}=a_{n}+i b_{n}$ are coordinates of point masses in complex form, Equation (5) specifies mapping

$$
L:\left(C_{z} \backslash A\right) \rightarrow C_{\zeta}
$$

of complex plane $C_{z}$ (with deleted points) to complex plane $C_{\zeta}$.

Mapping Jacobian (5) is given by following equation

$$
J=J(L)=\frac{\partial(\zeta, \bar{\zeta})}{\partial(z, \bar{z})} .
$$

Then equation

$$
J=0
$$

defines the critical set $\Theta$ of mapping (5). Set image $\Theta$ is a caustic $K$. The caustic is specified by mapping

$$
K=L(\Theta)
$$

Thus pre-image of the caustic is an image of critical set.

We build complete pre-image of the caustic in lens plane to define single-valued regions (Balk, Petrov \& Poluchin, 1976). Inverse mapping of (6) is defined by set

$$
Q=L^{-1}(K)=L^{-1}(L(\Theta)),
$$

This is the complete pre-image of caustic. Mapping $L^{-1}$ is not single-valued, hence sets $Q$ and $\Theta$ do not coincide. 


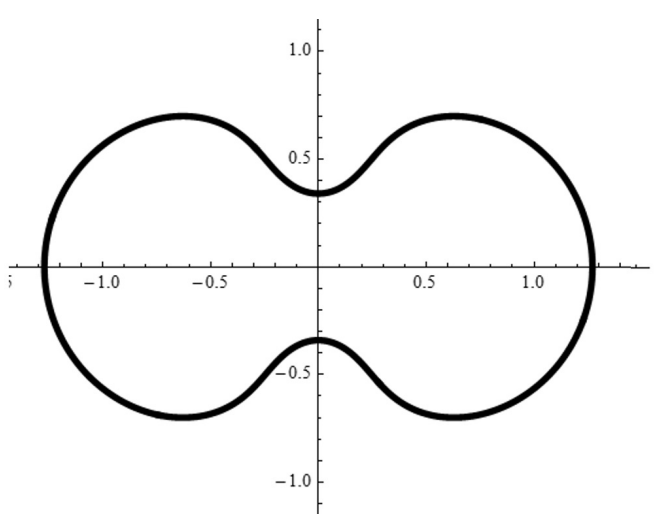

Figure 1: Critical curve of binary symmetrical lens with $a=0.5$

\section{Binary lens}

We demonstrate the algorithm, described in previous paragraph, for symmetrical binary lens with equal masses. Then from (2), we have:

$$
m_{1}=m_{2}=1 / 2 .
$$

Assume without loss of generality, that point masses are located on real axis with distance $a$ from origin, i.e.

$$
A_{1}=a, A_{2}=-a \text {. }
$$

In this case, equation (5) is given by:

$$
\zeta=z-\frac{\bar{z}}{\overline{z^{2}-a^{2}}}
$$

which defines mapping (6). Then Jacobian (7) is given by

$$
J=1-\frac{\left(a^{2}+z^{2}\right)\left(a^{2}+\bar{z}^{2}\right)}{\left(a^{2}-z^{2}\right)^{2}\left(a^{2}-\bar{z}^{2}\right)^{2}} .
$$

It follows from (8) that critical set $\Theta$ is defined by equation:

$$
1=\frac{\left(a^{2}+z^{2}\right)\left(a^{2}+\bar{z}^{2}\right)}{\left(a^{2}-z^{2}\right)^{2}\left(a^{2}-\bar{z}^{2}\right)^{2}} .
$$

It is known (Dank \& Heyrovsky 2015), that critical set, defined by equation (15), is split on a few classes depending on parameter $a$. When

$$
a<1 /(2 \sqrt{2}),
$$

critical curve consists of three closed Jordan curve - the two of them are inside the third. When

$$
a=1 /(2 \sqrt{2})
$$

critical set is represented as a closed curve with two self-crossing. When

$$
1 /(2 \sqrt{2})<a<1
$$

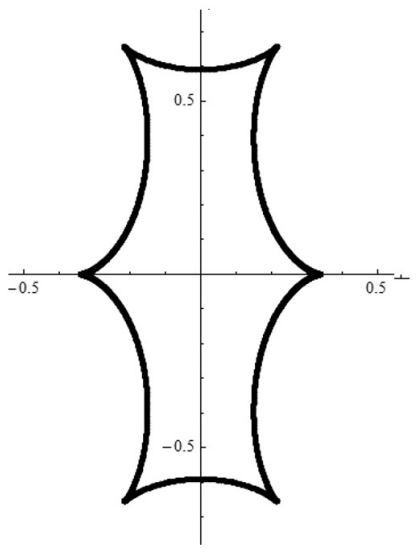

Figure 2: Caustic of symmetrical binary lens with $a=$ 0.5

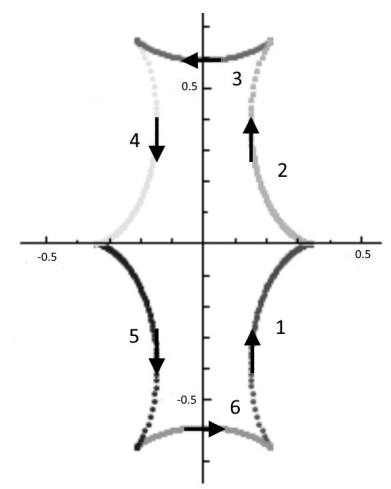

Figure 3: Caustic of symmetrical binary lens with orientation

there is a closed Jordan curve. With

$$
a>1,
$$

there are two closed Jordan curves, the one is outside the second.

We confine the study with case (18). We chose parameter $a=0.5$. The form of the critical curve is on Fig. 1. Caustic is the image of critical set (9). Thus, critical curve showed on Fig. 1 corresponds to caustic showed on Fig. 2.

For the following analysis we depict each arc of caustic with different style and give them number (arcs' orientation correspond to orientation that is accepted in complex analysis (see Fig. 3)).

Arc's orientation of complete caustic pre-image is induced by caustic orientation. Note, that caustic preimage (i.e. critical curve) in complete pre-image has opposite to critical curve orientation (Fig. 4).

It is necessary to build complete caustic pre-image according to (10) to define single-valued regions , as it was noted previously. In our case, we have curve (Fig. 5).

Complete caustic pre-image split lens plane into 8 two-dimensional regions. In order to define internal 


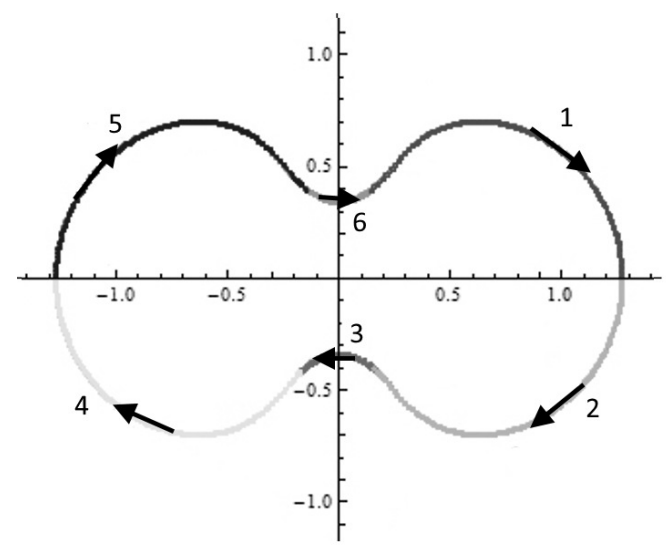

Figure 4: Critical curve of symmetrical binary lens with orientation

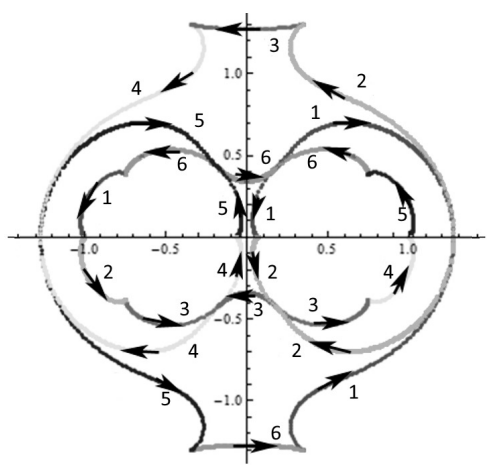

Figure 5: Complete caustic pre-image of symmetrical binary lens with orientation

and external regions on lens plane, we set three point sources on source plane, that is shown in form of triangle, square and star (Fig. 6).

Sources are located out of the caustic, on the caustic and inside the caustic respectively on Fig. 7. The caustic orientation is not shown on Fig. 7.

It is known, that source located inside the caustic has five images, on the caustic - four images, and out of the caustic - three images (Fig. 7).

It is known from the theory of functions of several complex variables, that an image of any of the five internal regions is interior of the caustic, when the mapping is $L$. And an image of any of the three exterior regions - caustic exterior. Moreover, restriction of mapping $L$ on the regions is homomorphism. Thus, eight regions are single-valued regions. Consequently, if we have five images, these images are in interior regions, and then there are no images in three exterior regions. Orientation, that is defined on the caustic, induces orientation on lens plane of each of eight regions. Boundary of four regions are oriented positively, and another four - negatively (Fig 8).

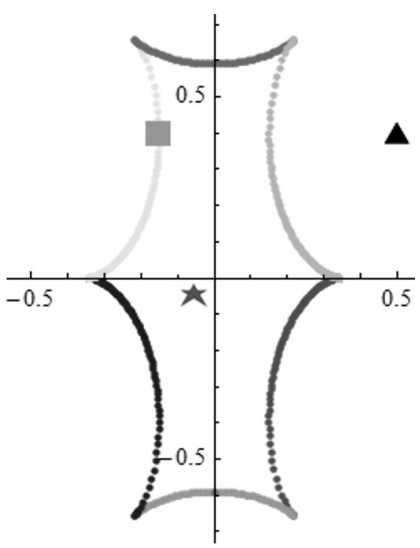

Figure 6: Caustic of symmetrical binary lens with three point sources

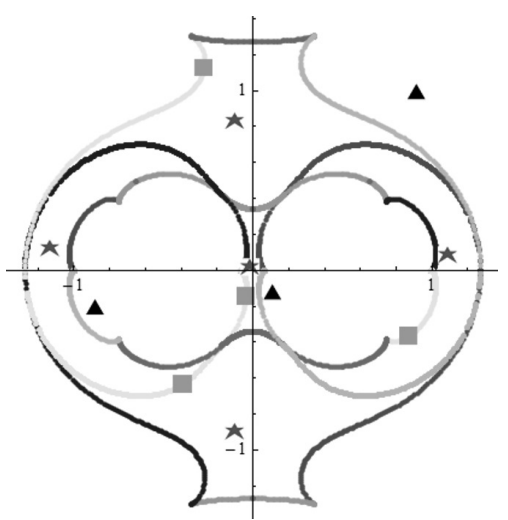

Figure 7: Distribution of caustic images and three point sources in symmetrical binary gravitational lens

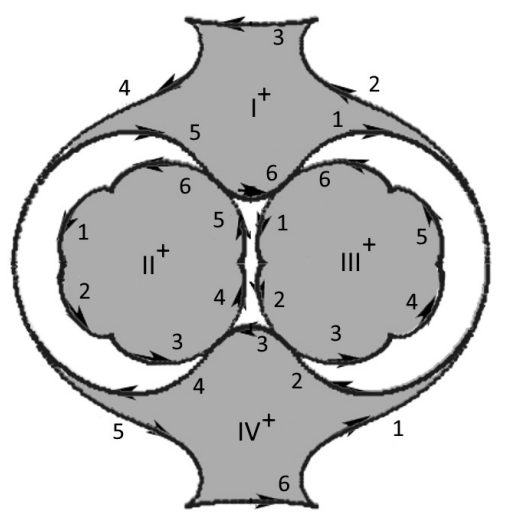

Figure 8: Division of complete caustic pre-image on positively (grey) and negatively (white) oriented regions

\section{References}

Balk M.B., Petrov V.A., Poluchin A.A.: 1976, Zadachnik-praktikum po teorii analiticheskih funkcij, Prosveschenie, Moskow (in Russian), 136p. 
Bliokh P.V., Minakov A.A.: 1989, Gravitational Kotvytskiy A.T., Bronza S.D., Shablenko V.Yu.: 2017, Lenses, Naukova Dumka, Kiev (in Russian), 240p. Odessa Astron. Publ., 30, 35.

Bronza S.D., Kotvytskiy A.T.: 2017, Bull. Kharkiv Kotvytskiy A.T., Bronza S.D.: 2016, Odessa Astron. Nat. Univ. "Physics", 26, 6.

Dank K., Heyrovsky D.: 2015, AJ, 806, 99.

Gaudi B. S., Bennett D. P., Udalski A. et al: 2008, Sci, 319, 927.

Gould A., Udalski A., Shin I.-G., et al: 2014, Sci, 345, 46.

Han C., Udalski A., Choi J.-Y., et al: 2013, ApJL, 762, L28. Publ., 29, 31.

Kotvytskiy A.T., Shablenko V.Yu., Bronza E.S.: 2018, Odessa Astron. Publ., 31, 24.

Schneider P., Ehlers J., Falco E.E.: 1999, Gravitational Lenses, Spr.-Verlag, Berlin, Heidelberg, 560p.

Zakharov A.F.: 1997, Gravitacionnye linzy $i$ mikrolinzy, Janus-K, Moskow (in Russian), 328p. 